\title{
Dismantling artificial levees and channel revetments promotes channel widening and regeneration of riparian vegetation over long river segments
}

\author{
Vanesa Martínez-Fernández , Eduardo González , Juan Carlos López-Almansa , \\ Sofía Maura González , Diego García de Jalón
}

\begin{abstract}
A B S T R A C T
Longitudinal structures manipulation can re-activate channel migration and thus restore flood-dependent riparian plant communities in human-constrained floodplains. However, it has been rarely implemented over long restored river segments and has been infrequently assessed while taking into account river conditions prior to restoration. This study describes the morphological and vegetation response to this type of restoration in a project completed in 2012 along a $21.6 \mathrm{~km}$ river segment in the Órbigo River (NW Spain). Land cover changes and channel planform evolution in the restored segment were compared with a downstream non-restored (control) segment and to an upstream unregulated (reference) segment before (2011) and shortly after (2014) the restoration implementation. Riparian vegetation was surveyed in 18 gravel bars of the three river segments four years after restoration completion (2016). The restored segment presented the largest increase of active channel area. Rejuvenation of landforms predominated over transition toward mature stages (succession) in the restored and the reference segment, while succession predominated in the control segment. The sinuosity and braiding indexes in the restored segment increased much more than in the reference and, especially, than in the control segment. Riparian plant communities that colonized gravel bars in the restored segment resembled those found in the unregulated segment and slightly differed from that found in the non-restored segment. Withinsegment variability was much higher, indicating the dependence of riparian plant communities on local processes. Although positive, our results showed that the high stability of floodplain areas in the human-constrained rivers of industrialized societies limits the short-term effectiveness of longitudinal structures manipulation as a restoration strategy. We also showed that assessments using relatively simple aerial photointerpretation and vegetation surveys in pioneer habitats can illustrate trajectories in river restoration projects shortly after their completion. Long-term monitoring of the geomorphic trajectory and associated plant communities, however, will help define the timing of future additional interventions to assure the natural resilience of riparian habitats.
\end{abstract}

\section{Introduction}

In degraded floodplains constrained by human activities, the regeneration of riparian vegetation is limited to narrow, unprotected areas running parallel to a main channel that no longer migrates (Cordes et al., 1997; Dixon et al., 2012; Martínez-Fernández et al., 2017). In these cases, the removal and setback of artificial levees and rip-rap channel revetments to re-activate channel migration, generally referred in this paper to as longitudinal structures manipulation, have been suggested as the most effective strategies for restoring endangered riparian plant communities (Biron et al., 2014; González et al., 2010; Göthe et al., 2016; Scott et al., 1996). Channel migration is necessary for the recurrent formation of open, moist surfaces that flood events left behind, such as bare gravel and sand bars, where pioneer, flood-dependent riparian plants can establish in the absence of competing vegetation (Mahoney and Rood, 1998; Scott et al., 1996).

The removal or setback of artificial levees and rip-rap channel revetments usually encounters strong social opposition: landowners are reluctant to yield their lands for restoration and neighboring communities fear higher flood risks following the dismantling of flood defenses 


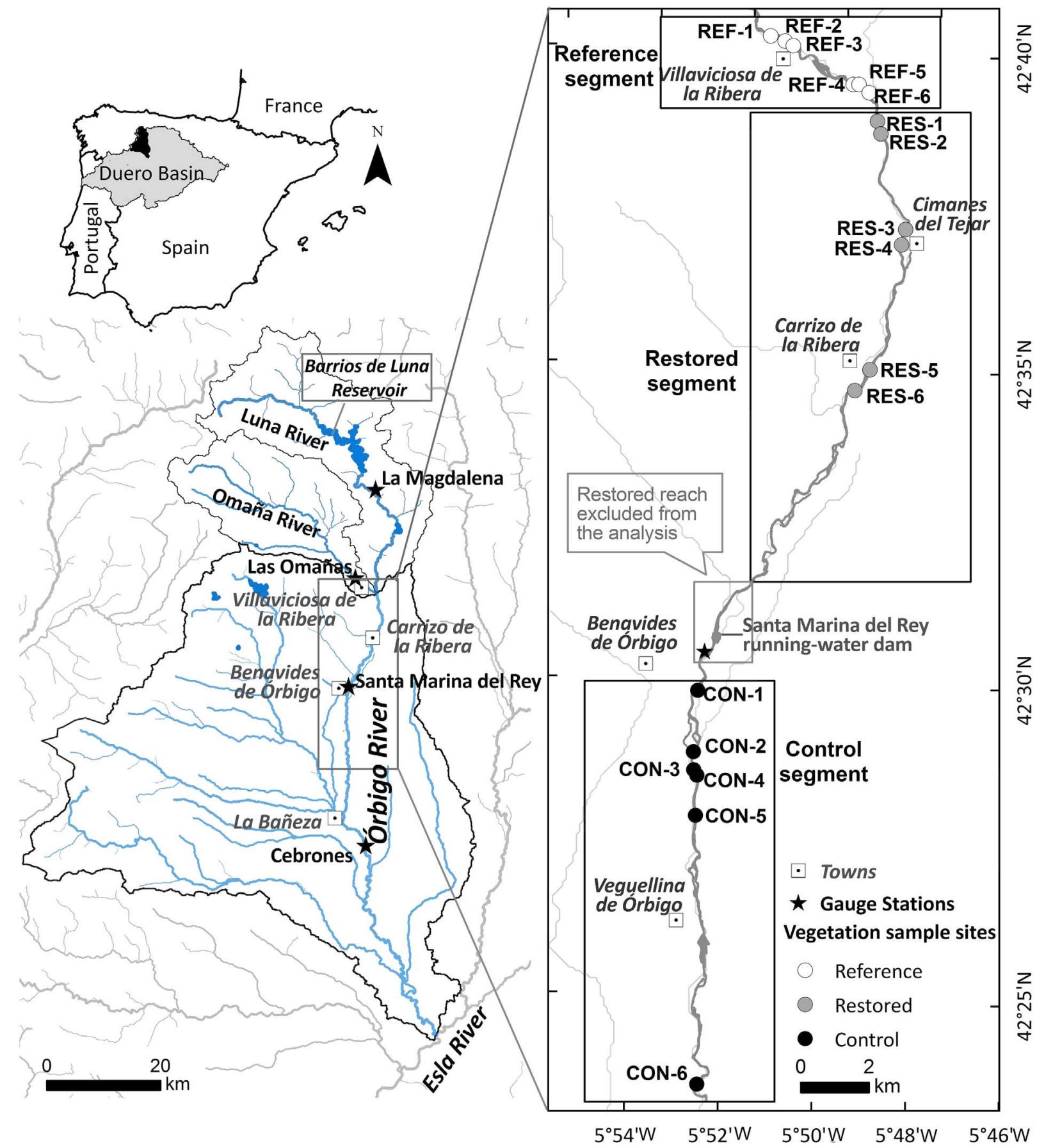

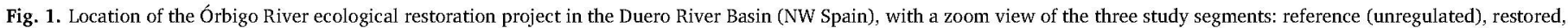
and control (non-restored), as well as the sampling sites for the vegetation survey: REF - reference, RES - restored, CON - control.

(Gumiero et al., 2013; Ollero, 2010). In this social context, this type of restoration actions has been employed much less often than needed, and its effectiveness in restoring riparian vegetation has not been frequently assessed (González et al., 2015). The few evaluations of this restoration method published to date have shown increases in riparian habitat heterogeneity and establishment of pioneer riparian plants when compared with unrestored control sites (e.g., Florsheim and Mount, 2002; González et al., 2017a; Göthe et al., 2016; Hering et al., 2015; Jähnig et al., 2009; Poppe et al., 2016; Rohde et al., 2005; note that in some of these papers the restoration actions are semantically confounded with the restoration goal as this restoration technique is generally referred as to "channel widening"). Surprisingly though, and despite recommendations (Bernhardt et al., 2007; González et al.,
2015), we are unaware of any study taking into account river conditions prior to restoration (before-after-reference design).

Most of the abovementioned published evaluations of longitudinal structures manipulation have studied their implementation over short river sections, usually less than $2 \mathrm{~km}$ and even less than $300 \mathrm{~m}$. Such a local-scale approach to river restoration might not be sufficient to maintain the key abiotic and biotic processes that sustain life in riparian areas, such as erosion, sedimentation, propagule dispersal, plant establishment, and organic matter decomposition, which are driven by factors, such as the flow regime or the flooding extent, that operate at multiple, higher and nested spatial levels, including segments of several kilometers in length, landscape units, and entire catchments (Gurnell et al., 2016). If this hierarchy of fluvial processes is not taken into 
account, the initial positive effects achieved by projects could vanish (Hughes et al., 2005). In this regard, upscaling of this type of restoration projects over longer river sections could be as efficient as (if not more) current local-scale approaches, with the advantage that the longer the restored river section, the greater the area of fluvial systems improved by restoration.

The aim of this study was to assess the effects of one of the most ambitious restoration projects mainly based on manipulation of longitudinal structures ever implemented in the world, along a $21.6 \mathrm{~km}$ long river segment in the Órbigo River (NW Spain). The study was conducted two and four years after the restoration project was implemented in 2012. In particular, we sought to assess the morphological and vegetation responses to restoration, namely the area gained by the river, in terms of its active channel, including pioneer habitats (gravel bars) and the colonisation of these areas by the flood-dependent riparian plant community.

The morphological evolution was analyzed by comparing the restored river segment to a nearby downstream non-restored segment (control) and to an upstream unregulated segment as a reference before (year 2011) and after (2014) restoration completion; that is, in a BACI design with comparisons of the same river segments Before versus After (B vs. A) as well as between different treatments (Control $-\mathrm{C}$ vs. Impact - I; Stewart-Oaten et al., 1986). However, vegetation was analyzed in a control-impact-reference design because flood-dependent riparian plant communities colonized pioneer habitats that emerged as a consequence of restoration and therefore did not exist prior to restoration.

This study is based on the following hypotheses: (i) the removal and setback of longitudinal structures would promote widening of the active channel, and (ii) vegetation communities would establish in new gravel bars emerging from channel widening and would resemble the ones found at reference sites (more natural) but would differ from those found at the non-restored segment.

\section{Project background}

\subsection{Study area: the Órbigo river, NW Spain}

The Órbigo River is located in the northern part of the Duero Basin (NW Spain) and is a tributary of the Esla River, which directly flows into the Duero River (Fig. 1). The Órbigo originates at the confluence of the Omaña River, unregulated, and the Luna River, regulated since 1956 with the completion of the Barrios de Luna reservoir. With a length of $108 \mathrm{~km}$, the Órbigo River drains $5039 \mathrm{~km}^{2}$. The Omaña and Luna sub-catchments mainly consist of mountainous and hilly areas with narrow valleys characterized by Paleozoic limestone, slate, and sandstone. Closer to the confluence of both rivers and also downstream in the Órbigo River, Quaternary sediments dominate with correspondingly wider river valleys in these areas (Rodríguez-Fernández, 2004). Annual precipitation ranges from $530 \mathrm{~mm}$ close to the Esla confluence to $1140 \mathrm{~mm}$ in the headwaters, being most abundant in winter and spring. The river has a pluvio-nival hydrological regime with a mean annual discharge of $25 \mathrm{~m}^{3} \mathrm{~s}^{-1}$ (Cebrones gauge station, 1972-2012).

The Órbigo River has been highly affected by pressure from two main human activities: 1) the flow regime regulation of the Luna River that keeps the summer base flow in the Órbigo river higher than normal to allow water extraction for irrigation purposes (Fig. 2); and 2) the conversion of the natural floodplain to farmlands and poplar plantations, which intensified during the second half of the 20th century with the construction of earth embankments, rip-raps, and levees. In turn, both of these activities have limited free stream-flow, changed the channel from a braiding planform in 1956 to the current single wandering planform, and caused artificial cutting of meanders and, ultimately, narrowing of the natural riparian corridor (Fig. 3).

Inspired by the Water Framework Directive (WFD) (2000/60/EC 23 October 2000), the Floods Directive (2007/60/EC 23 October 2007) and the Habitats Directive (92/43/EEC) within the National Strategy for River Restoration of Spain (González del Tánago et al., 2012), the Duero River Basin Water Agency (Confederación Hidrográfica del Duero, http://www.chduero.es) and other local authorities established the goal of improving the ecological condition of the river and created the ecological restoration project of the Órbigo River (CHD, 2011).

\subsection{The Órbigo river ecological restoration project}

The Órbigo River ecological restoration project covered a $21.6 \mathrm{~km}$ river segment located in the upper section of the river, i.e. from its source to a point located $1.5 \mathrm{~km}$ downstream from the Santa Marina del Rey running-water dam (Fig. 1), and encompassed a drainage area of $\sim 1605 \mathrm{~km}^{2}$. Restoration work began in autumn 2011 and was completed in autumn 2012 .

The main objective of the project was to recover the stream space and therefore the capacity to attenuate floods in the floodplain, which has been systematically encroached upon, resulting in much less frequent floods than before regulation. The project received an investment of $€ 2.2$ million, and was supported by local communities after a public participation process. The main actions consisted of eliminating earth embankments and rip-raps along a total of 13.4 longitudinal $\mathrm{km}$ and setting them back along another $5.2 \mathrm{~km}$.

\section{Methods}

\subsection{Study sites}

The morphologic and vegetation responses to the restoration actions were assessed through comparison of the three river segments: restored, control, and reference. The comparison of a restored river section to a nearby non-restored section is the frequent procedure when assessing restoration success (Hering et al., 2015; Jähnig et al., 2009; Poppe et al., 2016; Rohde et al., 2005) as restoration projects are rarely designed as scientific experiments and therefore are not possible to replicate. The first two segments were located in the Órbigo River under regulated conditions and the reference segment was located in the unregulated Omaña River (Fig. 1, Table 1). Flow conditions of these segments during the study time period (Fig. 2) show ordinary floods occurred along the six hydrologic years examined, with the highest peak flow at $231.5 \mathrm{~m}^{3} \mathrm{~s}^{-1}$ (April 2014). The non-restored segment was used as the control for the restored segment (Control vs. Impacted) and the unregulated segment was used to compare with semi-natural conditions. Only in the case of morphological analysis were segments analyzed before and after the restoration project implementation.

The restored segment was located within the $21.6 \mathrm{~km}$ restored section of the Órbigo River, from its origin to a point located $17.6 \mathrm{~km}$ downstream (Fig. 1). We did not assess the effects of restoration on the entire section to avoid possible alterations caused by the small running-water dam located at the end of the restored segment in Santa Marina del Rey and the construction of a water treatment plant (operational since June 2013) adjacent to the main channel, which involved earth movements in the main channel. The segment that was removed from the analysis only represented $4 \mathrm{~km}$ ( $18 \%$ of the entire restored section).

A non-restored control segment was selected to serve as negative reference for the restored section. This control segment was located immediately downstream of the restored section in the Órbigo River and was $13.7 \mathrm{~km}$ in length (Fig. 1). The floodplain at the control segment was narrower than at the restored segment prior to restoration frequently due to the presence of earth embankments and rip-raps that hinders channel migration (Table 1). Therefore, although conditions for comparison are not optimal, given that replications in rivers are rarely possible, the control segment was considered adequate for the project restoration assessment.

Finally, a reference segment was selected to compare the evolution of semi-natural conditions with the restored and the control segments. A 


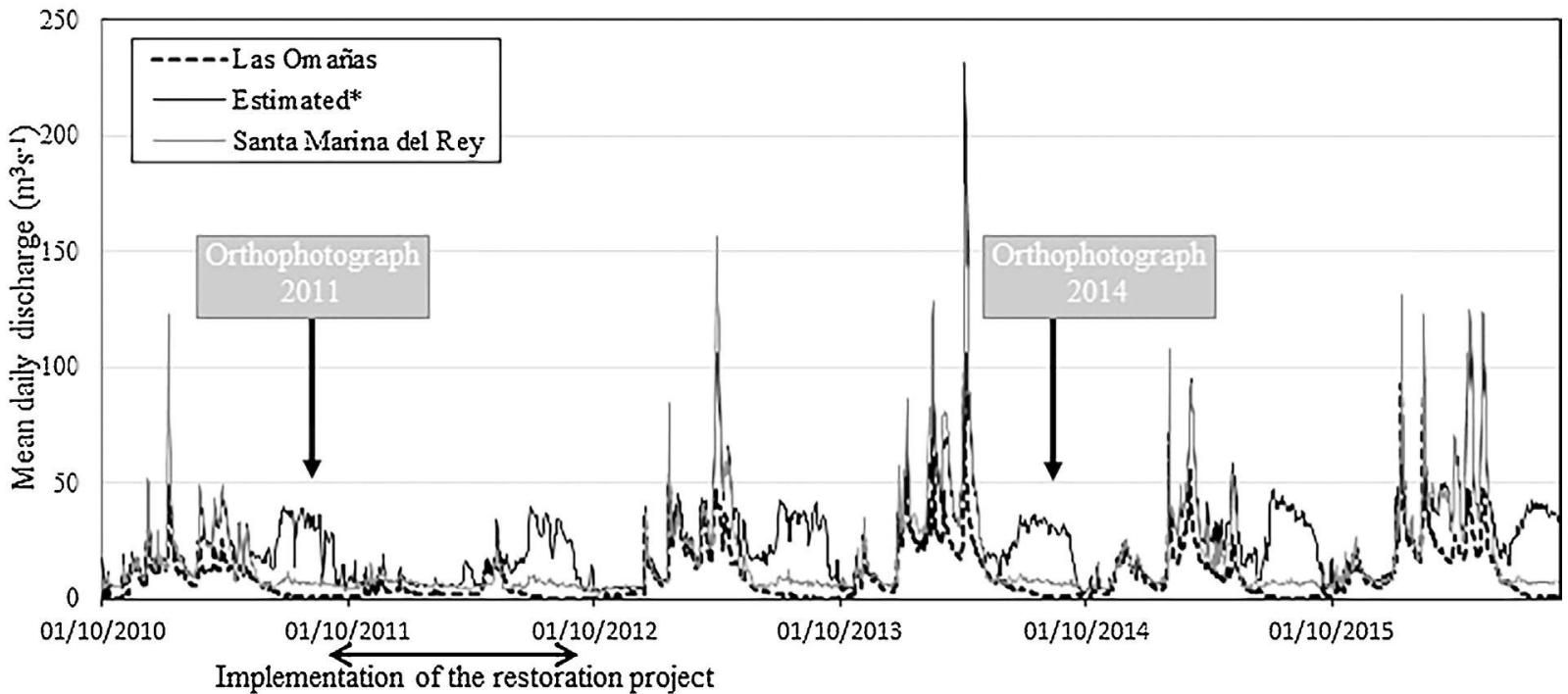

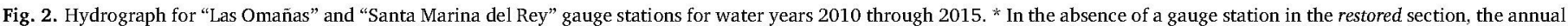

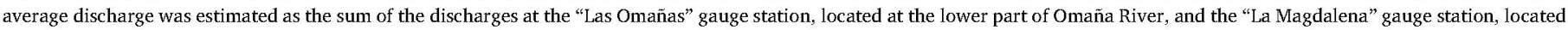
in the Luna River. See Fig. 1 for location of the gauge stations.

$6.9 \mathrm{~km}$ long river segment of the Omaña River located immediately upstream from its confluence with the Luna River was selected for this purpose. It was not possible to select a longer segment if similar, unconfined valley conditions to the Órbigo River were to be preserved. The Omaña River was not dammed, but at some locations flood defenses were built to prevent adjacent field crops from flooding and therefore, to a lesser extent than in the Órbigo and Luna rivers, channel migration was also limited.

\subsection{Morphological analysis of the Órbigo river system}

To evaluate the morphological changes in the river in a BACI design, aerial orthophotographs from the year 2011 (before restoration) and
2014 (the latest orthophotographs available after restoration), all with a $0.5 \mathrm{~m}$ spatial resolution (available at www.ign.es, Instituto Geográfico Nacional of Spain) were analyzed using ArcGis $10.1^{\circ}$. Both orthophotographs were taken under similar water-level conditions, between 15th July and 15th August (mean flow discharge during the periods when pictures were taken ranging from 0.8 to $1.1 \mathrm{~m}^{3} \mathrm{~s}^{-1}$ in "Las Omañas" gauge station (reference segment); from 33.4 to $32.4 \mathrm{~m}^{3} \mathrm{~s}^{-1}$ in the restored segment, and from 6.7 to $7.3 \mathrm{~m}^{3} \mathrm{~s}^{-1}$ in "Santa Marina" gauge station (control segment), for summers of 2011 and 2014, respectively).

Three cover types were digitized along the studied segments in the two aerial photographs: active channel, or surface covered by water including bare gravel bars (Gurnell et al., 2001); vegetated bars, or
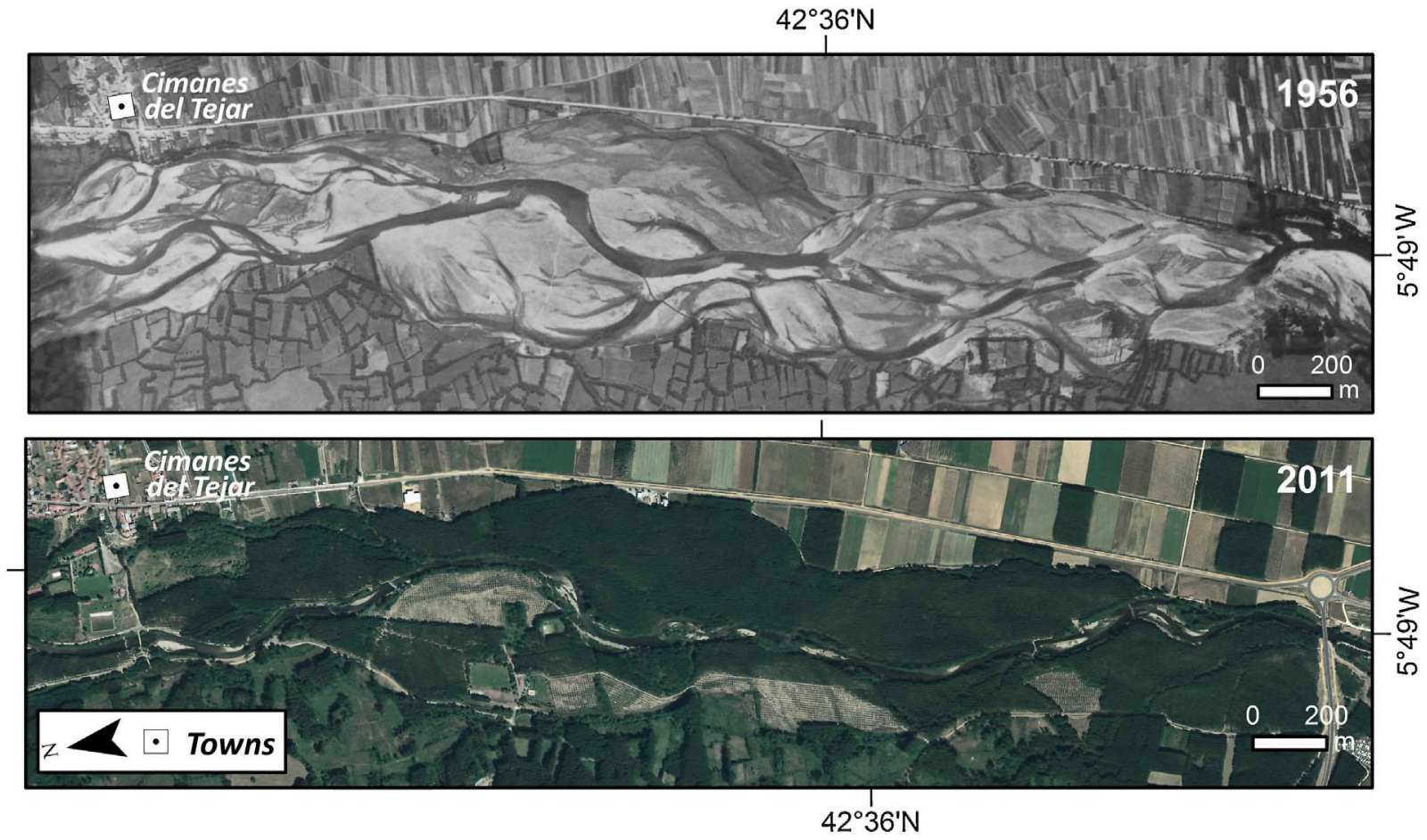

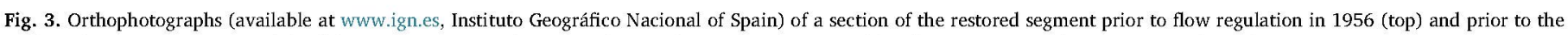
ecological restoration project of the Órbigo River in 2011 (bottom). The prevalence of non-vegetated landforms in 1956 indicates greater channel migration. 
Table 1

Characteristics of the three study segments.

\begin{tabular}{llll}
\hline & Reference & Restored & Control \\
\hline River & Omaña & Órbigo & Órbigo \\
Catchment size $\left(\mathrm{km}^{2}\right)$ & 516 & 1558 & 1650 \\
Segment length $(\mathrm{km})$ & 6.9 & 17.6 & 13.7 \\
Thalweg altitude range $(\mathrm{m})$ & $938-901$ & $899-845$ & $832-791$ \\
Channel Slope $(\%)$ & 5.4 & 3.2 & 2.9 \\
Mean annual discharge & 10.2 & 25.2 & 16.0 \\
$\quad\left(\mathrm{~m}^{3} \mathrm{~s}^{-1}\right)^{*}$ & Las Omañas & Estimated & \\
Gauge station & & & Santa Marina del \\
Floodplain width $(\mathrm{m})^{* * * *}$ & 819 & 540 & 250
\end{tabular}

*Calculated for the period 1995-2015 from available data in http://sig.mapama.es/redesseguimiento/visor.html?herramienta $=$ Aforos

*In the absence of a gauge station in the restored section, the annual average discharge was estimated as the sum of the discharges at the "Las Omañas" gauge station, located at the lower part of Omaña River, and the "La Magdalena" gauge station, located in the Luna River. Note that the mean annual discharge in the restored segment is much higher than in the control segment as water abstraction occurs for irrigation.

***Calculated as the total area limited to the 10-year recurrence interval (CHD, 2010) in each segment divided by the length of the segment.

gravel bars either partially covered by vegetation in dense patches or totally covered by scattered vegetation; and floodplain, or all other landforms limited to the 10-year recurrence interval (CHD, 2010).

We used the three cover types to perform two data analyses. First, the total area of each cover type was calculated in each segment to compare the net surface change between 2011 and 2014. Second, to elucidate the transitions between cover types, the amount of area that remained in the same cover type or changed from one type to another between 2011 and 2014 was classified into four categories of transitions: 1) polygons that remained as active channel type from 2011 to 2014 were considered permanent active channel; 2) transitions implying a change towards earlier stages in the morphological succession were considered rejuvenation, i.e. vegetated bars or floodplain towards active channel; 3) the area that remained as floodplain from 2011 to 2014 was considered permanent floodplain; and 4) any change towards mature states, i.e. areas that in 2014 became more morphologically stable than in 2011, and vegetated bars present in both years, was classified as succession. The "permanent floodplain" category could have been included in the "succession" type, but we anticipated that the area of permanent floodplain would be much larger than that of succession and, therefore, having only one category would have masked the transitions at the earlier succession stages now denoted by category \#4 (succession). Every polygon narrower than $2 \mathrm{~m}$ was discarded from calculations of transitions in order to avoid boundary differences during the delimitation of the cover types.

To facilitate comparisons between the three river segments of different lengths, in addition to expressing results as areas (ha), we also expressed results as an "average width of change" $(\mathrm{m})$. To do this, the net change in area of each cover type, in the first analysis, or the area corresponding to each transition, in the second analysis, was divided by the length of the corresponding segment.

Finally, to assess channel planform changes, channel sinuosity and braiding indices, and the proportion of multiple channels were calculated along the three segments. The channel sinuosity index was calculated as the ratio between the (main) channel length and the valley length (Fryirs and Brierley, 2013). The braiding index is the number of channels separated by bars and was calculated as the average count of wetted channels along the segment (Egozi and Ashmore, 2008). The proportion of multiple channels was quantified as the percentage of the entire segment length in which there was more than one channel. Also, three meanders that we considered representative of the entire restored section were analyzed separately to exemplify channel changes in the restored segment and to separate the importance of the open water vs.
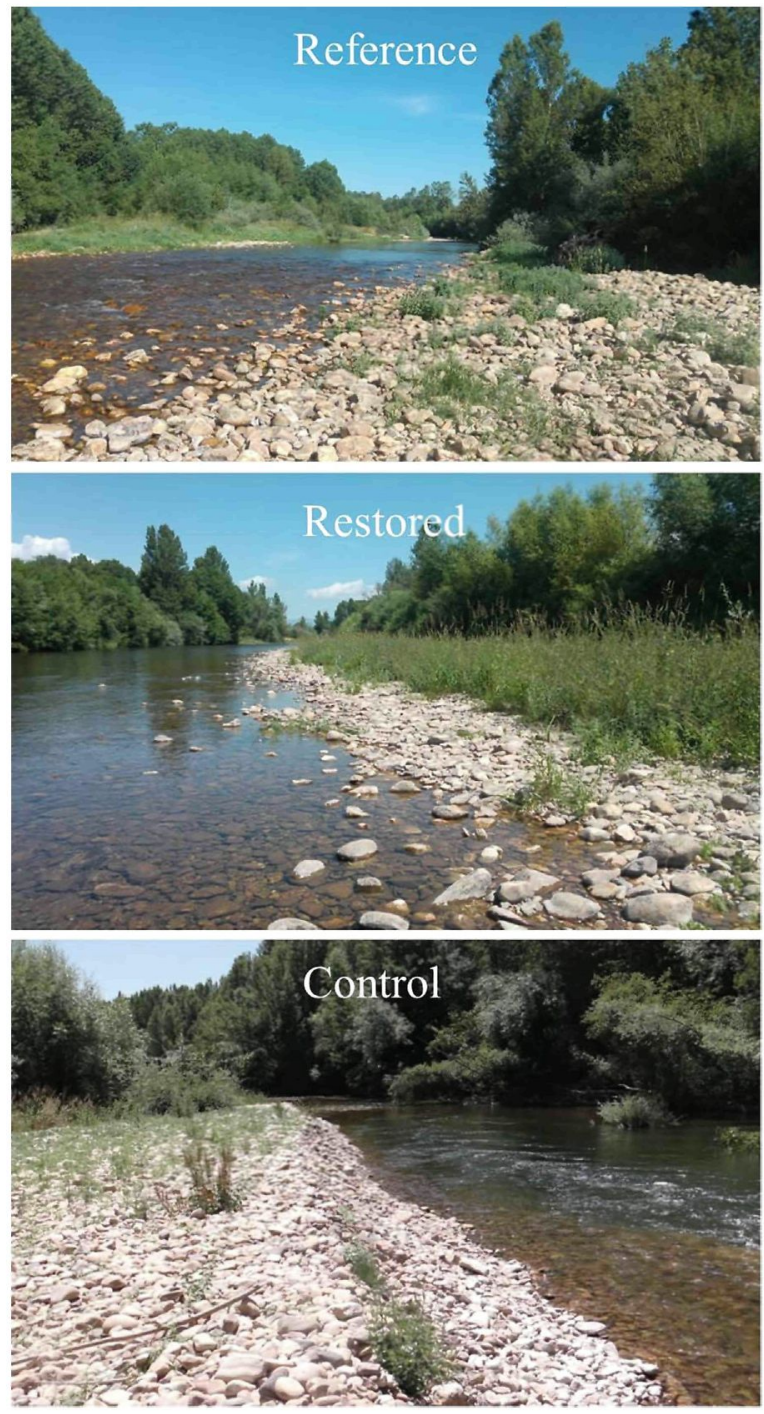

Fig. 4. Images of representative sample sites in the reference (REF-2), restoration (RES1), and control (CON-2) segments. See Fig. 1 for location of the sites and Appendix A for detailed information about vegetation composition (Photos: Juan Carlos López-Almansa).

bare gravel bars in the accounting of change in active channel area.

\subsection{Field surveys for vegetation}

A total of 18 representative gravel bars (six in the restored, six in the reference, and six in the control segment, Figs. 1 and 4) were selected along the study segments for detailed vegetation surveys. Those sites were selected based on site accessibility and lowest human disturbance. During the early summer (6-9 July) of 2016 , the vegetation in each of the 18 study sites was sampled. Vegetation could not be sampled at the time of the latest orthophotograph available (2014) because our financial support for this work started in 2016. At each site, three to nine transects ranging from 10 to $40 \mathrm{~m}$ in length were set up perpendicular to the river channel. The number and length of transects depended on site size (range: $600-7000 \mathrm{~m}^{2}$, calculated on the 2014 aerial photograph), shape, and heterogeneity of vegetation. At each transect, vegetation was recorded using the line-point intercept method (Bonham 1989). All species intercepted on a vertical line from the ground to the tree canopy were identified and noted every $10 \mathrm{~cm}$ along each transect. This information was used to estimate the cover of each species at each site. When a species was present in different forms (heights) at the same sampling point, it was counted only once, such that the maximal cover value for a species at a given site was $100 \%$. The number of pinpoints in 
a site ranged between 500 and 1500 . Finally, data for substrate characterization was collected by randomly selecting a piece of gravel every $1 \mathrm{~m}$ along each transect to record the diameter of the intermediate axis ("b-axis" sensu Krumbein 1941) to the nearest millimeter. This information served to report the superficial grain size distribution (Wolman, 1954).

\subsection{Statistical analyses of vegetation and grain size distribution data}

In the case of vegetation, first, the $\alpha$-diversity represented by Shannon's diversity index of the entire plant community was compared between the three river segments using $t$-tests $(P<0.05)$. Beta-diversity was explored between the three river segments using analysis of similarity (ANOSIM) with Euclidean distances on Hellinger-transformed vegetation data (Legendre and Gallagher 2001), and withinriver segment types (i.e., heterogeneity of each river segment) using the following formula: $\Sigma$ (Hellinger's transformed distances of the $\mathrm{n}$ sites) ${ }^{2} /$ (n*(n-1)). Significance of the ANOSIM tests was computed by permutation of group membership with 9999 randomized runs. Second, the main gradients of variability of the entire plant community in the 18 sites were summarized in a principal component analysis run on the Hellinger-transformed vegetation matrix. Then, the site scores of each site type along the two main PCA axes (first two main gradients) were compared using $t$-tests $(P<0.05)$. Regarding grain size data, the 50th percentile was calculated at site level, i.e. clustering transects of each of the 18 sampled sites, and was correlated to the site scores of the main PCA axes using Spearman's coefficient. The grain size diversity was also calculated at site level with the non-parametric approach of Quintana et al. (2008), and was correlated to the site scores of the main PCA axes using Spearman's coefficient.

All the analyses were conducted using $\mathrm{R}$ v. 3.2 .4 software $(\mathrm{R}$ Development Core Team, 2016). The functions decostand, anosim, and rda of package vegan (Oksanen et al., 2013) were used to run the Hellinger transformation, the ANOSIM, and the PCA analysis, respectively.

\section{Results}

\subsection{Morphological response to restoration along the Órbigo river system (2011-2014)}

The restored segment presented the highest increase in active channel area between 2011 and 2014 compared to the reference and control segments, either expressed as change in area (Fig. 5) or average width (Fig. 6). Vegetated bars decreased in the restored segment, but much less than in the control segment, while they greatly increased in the reference segment (Figs. 5 and 6). The change in floodplain area was very small in the three study segments compared to the total

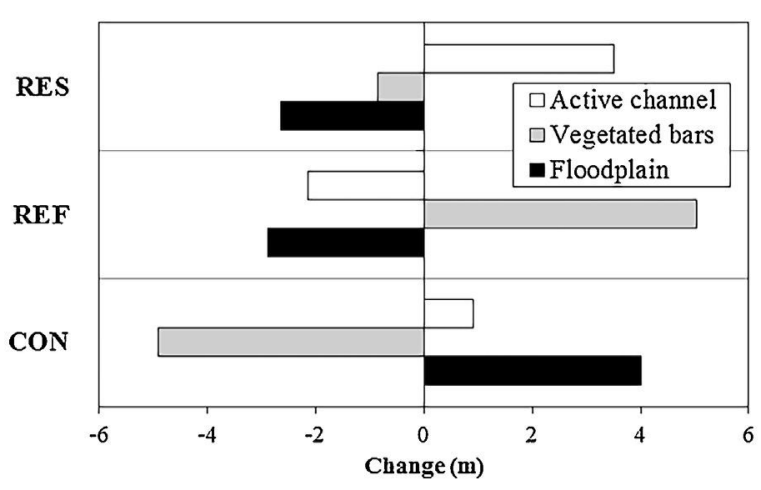

Fig. 6. Average width of variation for the three cover types (active channel, vegetated bar, and floodplain) along the three segments (RES, REF and CON for reference, restored and control respectively) for 2011-2014.

surface and length of this cover type (Figs. 5 and 6). However, in absolute terms, the changes were similar to the other land cover types. Restoration achieved reductions of floodplain widths similar to that found in the reference segment. Conversely, this cover type markedly increased in the control segment.

Over the study period 2011-2014, rejuvenation transitions predominated over succession in the restored and reference segments, but much more in the former than in the latter, with rejuvenation $50 \%$ higher than succession in the restored segment versus $15 \%$ higher in the reference segment (Fig. 7). Succession predominated over rejuvenation in the control segment ( $52 \%$ higher). The turnover of floodplain areas (i.e., permanent floodplain, Fig. 6) was intermediate in the restored segment compared to the reference (higher) and control (lower) segments, following the same order found for floodplain widths (reference $>$ restored $>$ control, Table 1). The largest turnover of active channels (i.e., permanent active channel, Fig. 7) also occurred in the reference river segment. Permanent active channel in the restored segment was $6.5 \%$ higher than in the control and $14.8 \%$ lower than in the reference segment.

The increase in active channel area (and width) in the restored segment came with greater increases in channel sinuosity index, braiding index and proportion of multiple channels than in the reference and the control segments, leading to a more complex river planform after restoration (Table 2). Three short river sections in the restored segment illustrate these general observations. In the first example (Fig. 8a-b), the active channel widened on average from 30.6 to $48.8 \mathrm{~m}$ and a point gravel bar of $5300 \mathrm{~m}^{2}$ in size emerged. The second example (Fig. 8c-d) also illustrated an increase of average active channel width $(+16.6 \mathrm{~m})$ and bare gravel surface (from 700 to $6800 \mathrm{~m}^{2}$ ), together with an increase in sinuosity index from 1.02 to

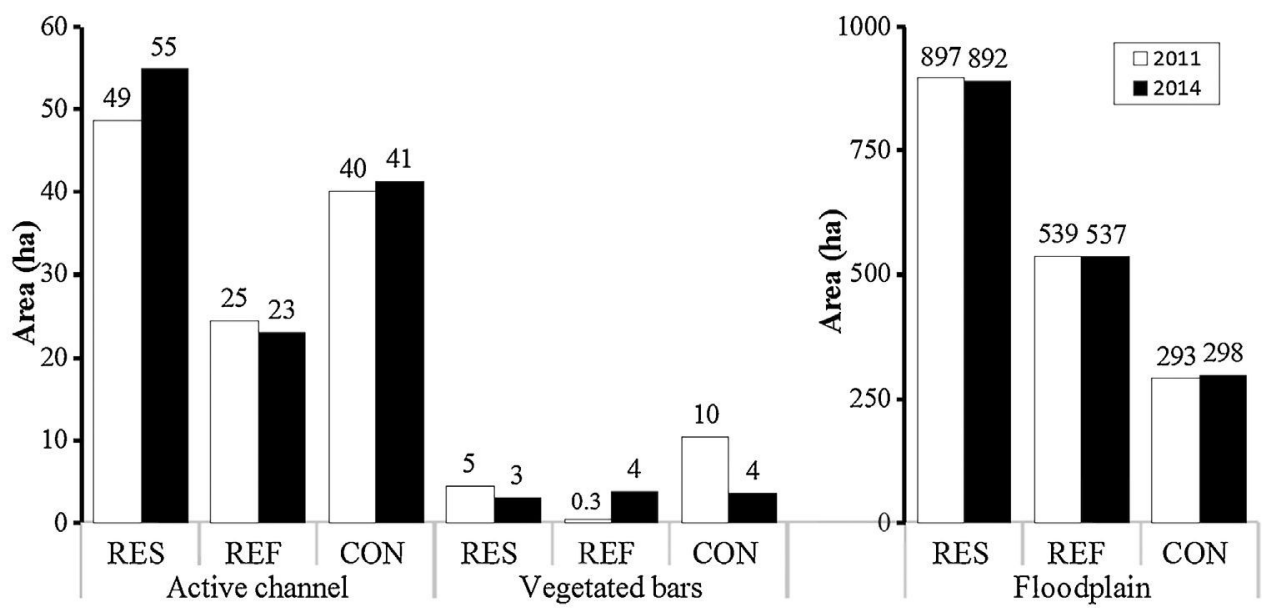

Fig. 5. Total area of cover types (active channel, vegetated bars, and floodplain) along the three segments (RES, REF and CON for restored, reference and control respectively) for 2011-2014. Note that the $y$ axis scale is different for the floodplain category. 


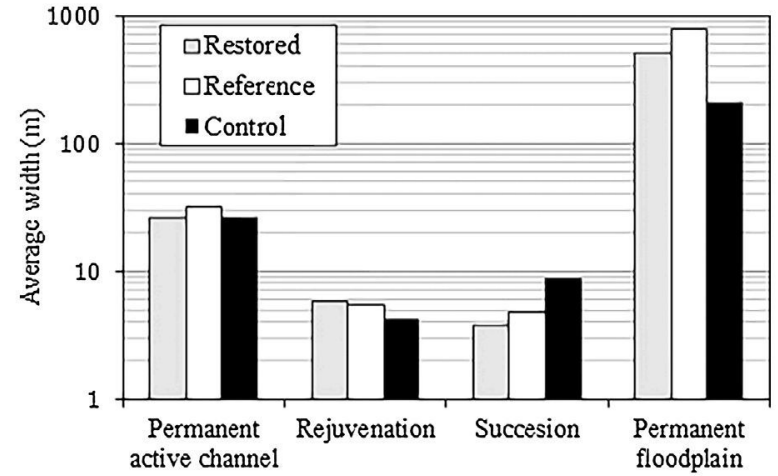

Fig. 7. Transitions between cover types expressed as average width of change (m). Data are displayed on a logarithmic scale. See definition of transition categories and explanation of calculations in the text (Methods section).

1.08. In the third example (Fig. 8e-f), the active channel widened on average from $18.9 \mathrm{~m}$ to $51.8 \mathrm{~m}$ and new bare gravel surfaces of $2860 \mathrm{~m}^{2}$ appeared after the removal of a rip-rap. This led the channel planform to be more complex as indicated by the increase of the average number of channels from 1.0 to 1.9 .

\subsection{Vegetation community response to restoration}

The vegetation at the three types of sites was equally diverse in absolute terms (no differences in $\alpha$-diversity, Table 3). The most common species (i.e., proportion of sites present $>80 \%$; frequency of occurrence when present $>3 \%$ ) were the forb Persicaria maculosa, the grass Phalaris arundinacea, and the shrubs Salix purpurea and S. salviifolia (Appendix A). The source of diversity, however, did differ both within and between site types, but differences were notably greater within, rather than between, site types (values in diagonal larger than inside the triangle; $\beta$-diversity, Table 3 ). In fact, only the plant communities of restored and control sites were significantly different $(\beta$ diversity $=0.39$ ). Restored sites were the most heterogeneous, but this was mainly due to one site (RES-3) being different from the others. If RES- 3 was removed from the analysis, the $\beta$-diversity of the remaining five sites was 0.36 , a much lower value than that for reference and control sites (diagonal; $\beta$-diversity, Table 3 ). Restored sites had a coarser texture than reference and control sites (mean d50 \pm 1 SE: Restored $=78 \mathrm{a} \pm 8 \mathrm{~mm} ; \quad$ Reference $=53 \mathrm{~b} \pm 7 \mathrm{~mm}$, Control $=59 \mathrm{~b} \pm 7 \mathrm{~mm}$, letters indicating homogeneous groups after $t$ tests, $\mathrm{P}<0.05$ ) and a higher grain size diversity than control sites (mean grain size diversity \pm 1 SE: Restored $=4.4 \mathrm{a} \pm 0.2$; Reference $=4.2 \mathrm{ab} \pm 0.3$, Control $=4.0 \mathrm{~b} \pm 0.3$, letters indicating homogeneous groups after $t$-tests, $\mathrm{P}<0.05$ ).

PCA results (Fig. 9) showed that a great amount of variability (43\%) of the entire plant community in the 18 sites could be summarized in only two axes. A first gradient of variability explained $25 \%$ and was related to the frequency and duration of submersions, with two hygrophilous species, Persicaria maculosa and, to a lesser extent, Polygonum aviculare, very negatively loaded. Species that still need wet soils but better tolerate drought periods and coarser soils such as Salix purpurea, Rorippa sylvestris, and Mentha longifolia were in the positive end of the gradient (species scores, PC1, Fig. 9). This axis separated restored sites (positive values, except for site RES-3) from reference and control (negative values), as shown by $t$-tests (site scores, PC1, Fig. 9). A second gradient explained $18 \%$ of the vegetation variability and was related to the vegetation structure. Woody species, such as Salix fragilis, S. salviifolia, and Populus nigra dominated the negative end of the gradient with the least coarse soils, while forbs such as Persicaria maculosa, Rorippa sylvestris, and Mentha longifolia, and the shrubby willow Salix purpurea, were the most positively loaded (species scores, PC2, Fig. 9). $\mathrm{T}$ tests on this axis also separated control from restored sites, with all of the latter in the positive side of the axis (site scores, PC2, Fig. 9).

\section{Discussion}

\subsection{Upscaled channel widening can modify the morphology of an entire river segment}

As hypothesized, only two years after the completion of the restoration actions, the $17.6 \mathrm{~km}$ restored segment experienced the largest widening of the active channel compared to the control and reference segments. The process of channel widening has also come along with transitions of cover types toward initial seral stages. That is, the restored segment presented the largest transitions toward active channel dynamics (rejuvenation) and the smallest transitions toward mature stages (succession). Moreover, river complexity, illustrated by channel sinuosity, braiding (average number of channels) and the proportion of multiple channels, increased more in the restored segment than in the reference and control segments. These positive results show that the removal or setback of longitudinal structures can efficiently recover some degree of geomorphic dynamism as long as ordinary floods promote sediment transport and deposition in a wider fluvial space that became available following restoration. This dynamism normally results in the recurrent formation of bare gravel bars in which pioneer vegetation can establish. Such positive effects could be achieved not only in small river sections $(<1 \mathrm{~km}$ ), as has been shown previously by other authors, but in entire river segments $(>20 \mathrm{~km})$. While we have thus shown that channel widening can be successfully scaled up in the longitudinal (i.e., upstream-downstream) axis of rivers by manipulating longitudinal structures over long river segments, caution must balance optimism since the dynamism of the channel in the restored areas is still much more limited than it was before regulation in the lateral river gradient. That is, a huge area remained as floodplain (permanent floodplain type in our transition analysis). Changes among the other landforms were almost negligible in absolute terms.

With few studies reporting the river morphological response to longitudinal structures manipulation, there is a lack of standardized hydromorphological parameters to compare the effectiveness of this kind of restoration project. Previous studies generally compared some morphological features of the restored river sections, such as landscape metrics of habitat types, stream flow velocity patterns, and depth variability, with control, unrestored pairs (Jähnig et al., 2009; Poppe et al., 2016; Rohde et al., 2005). We show in this paper that using relatively simple aerial photointerpretation in a BACI (Before-After Control-Impact) design to delineate basic landforms and calculate their

Table 2

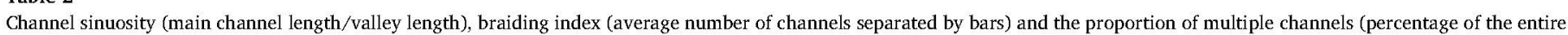
segment length in which there was more than one channel) for the entire three study segments.

\begin{tabular}{|c|c|c|c|c|c|c|}
\hline \multirow[b]{2}{*}{ Segment } & \multicolumn{2}{|l|}{ Sinuosity index } & \multicolumn{2}{|l|}{ Braiding index } & \multicolumn{2}{|c|}{ Proportion of multiple channels (\%) } \\
\hline & $\begin{array}{l}2011 \text { (prior to } \\
\text { restoration) }\end{array}$ & $\begin{array}{l}2014 \text { (before } \\
\text { restoration) }\end{array}$ & $\begin{array}{l}2011 \text { (prior to } \\
\text { restoration) }\end{array}$ & $\begin{array}{l}2014 \text { (before } \\
\text { restoration) }\end{array}$ & $\begin{array}{l}2011 \text { (prior to } \\
\text { restoration) }\end{array}$ & 2014 (before restoration) \\
\hline Restored & 1.17 & 1.28 & 1.15 & 1.24 & 7.9 & 11.5 \\
\hline Reference & 1.17 & 1.20 & 1.33 & 1.40 & 17.5 & 17.8 \\
\hline Control & 1.14 & 1.13 & 1.11 & 1.14 & 10.9 & 9.3 \\
\hline
\end{tabular}




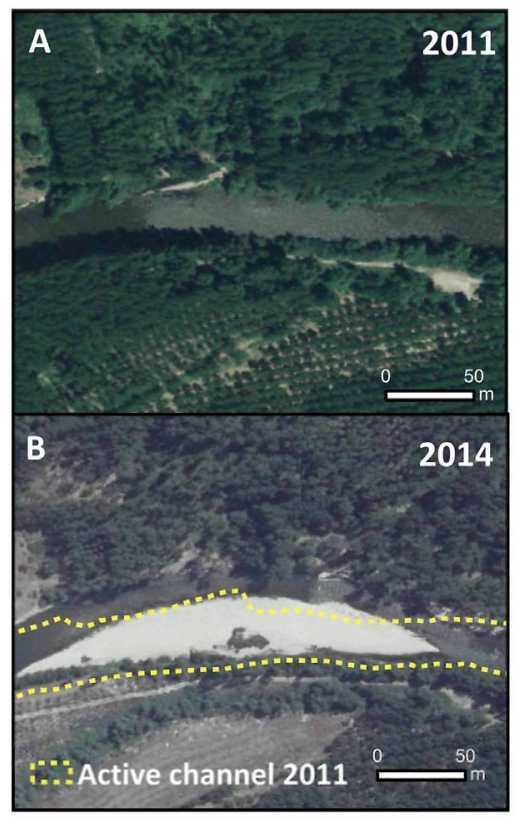

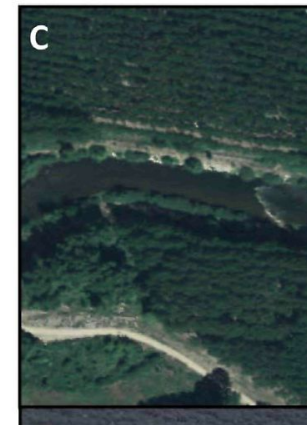

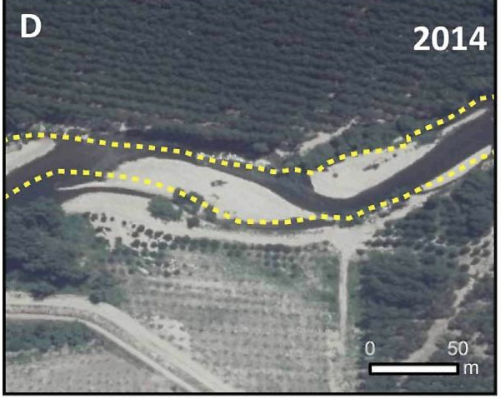

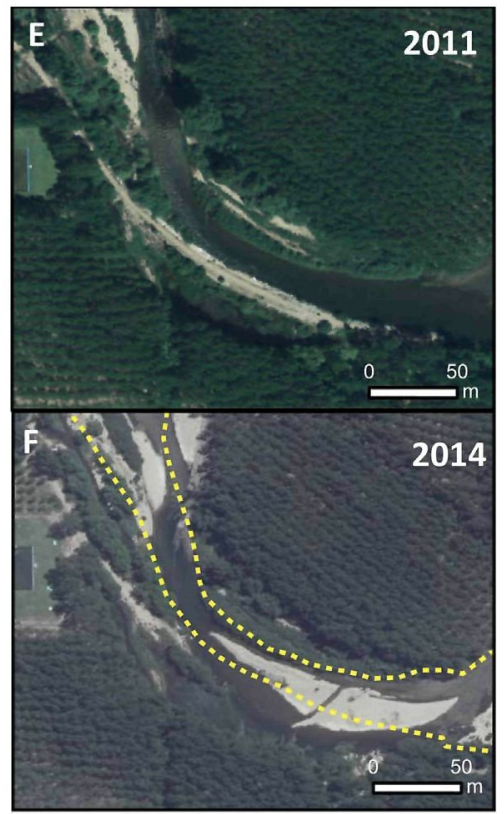

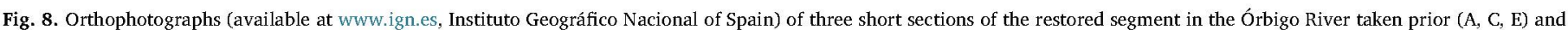

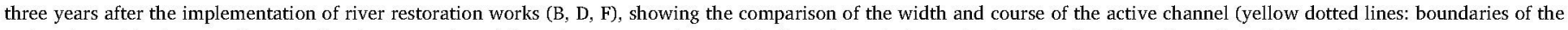
active channel in the 2011 images). (For interpretation of the references to colour in this figure legend, the reader is referred to the web version of this article.)

Table 3

$\alpha$-diversity and B-diversity of the plant community in the $\mathbf{1 8}$ study sites. In the diagonal, within site types ß-diversity was based on a Hellinger transformation (i.e., dissimilarity of plant composition between the six site replicates of each category; note that no statistical test was done and therefore P-values were not reported). In the rest of the triangle, between site types B-diversity was represented by ANOSIM statistic R showing dissimilarity of the floristic composition (Hellinger-transformed) between the three types of sites, with the anosim function of the vegan package 0 . Both within and between site types B-diversity ranged from 0 (maximum similarity) to 1 (maximum dissimilarity). Letters indicate homogeneous groups after $t$-tests $(P<0.05)$. n.s. non-significant.

\begin{tabular}{llll}
\hline $\begin{array}{l}\alpha \text {-diversity } \\
\text { Shannon's diversity index } \\
\text { B-diversity }\end{array}$ & $\begin{array}{l}\text { Reference } \\
2.17 \mathrm{a} \pm 0.13 \\
\text { Reference }\end{array}$ & $\begin{array}{l}\text { Restored } \\
1.91 \mathrm{a} \pm 0.18 \\
\text { Restored }\end{array}$ & $\begin{array}{l}\text { Control } \\
2.22 \mathrm{a} \pm 0.11 \\
\text { Control }\end{array}$ \\
\hline $\begin{array}{l}\text { Reference } \\
\text { Restored } \\
\text { Control }\end{array}$ & 0.52 & & \\
\hline
\end{tabular}

changes in cover, and basic geomorphic metrics, such as channel sinuosity and braiding, is also helpful to assess the effectiveness of channel widening over long river sections. Making evaluation metrics accessible to managers and restoration practitioners will encourage them to evaluate more projects and inform adaptive management (González et al., 2014).

\subsection{Upscaled channel widening helps recruitment of flood-dependent} riparian plant communities similar to the ones found in the reference segment

In our study, no differences were found between the riparian plant communities colonizing the gravel bars sampled in the restored and reference river segments, neither in terms of alpha nor beta diversity. This confirmed the first part of our second hypothesis and concurred with previous studies that showed that the bare gravel bars that emerged as a result of channel widening are appropriate for the establishment of flood-dependent riparian plants similar to the ones found on natural gravel bars (González et al., 2017a; Rohde et al., 2005). In our opinion, these observations legitimate passive restoration approaches that aim at reconstituting functional processes to mimic natural dynamics, as opposed to other more interventionist, often more costly, active restoration approaches, such as floodplain reconfiguration

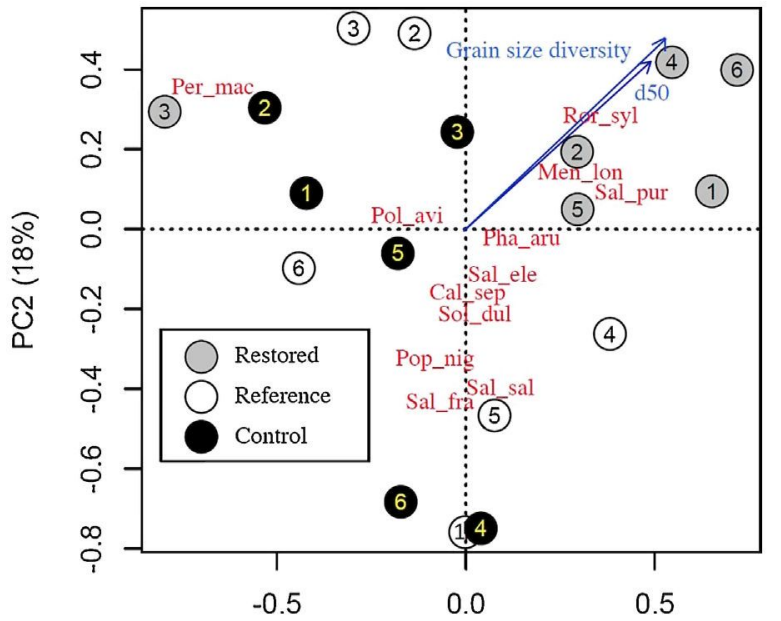

Fig. 9. Plot of the two first axes of the Principal Component Analysis (PCA) processed from the community composition (Hellinger transformation, red acronyms) observed at the 18 study sites. Only the scores of the $10 \%$ species with the highest weight in the two first axes of the PCA are shown, multiplied by 1.2 to improve visual clarity. The positions of the three site types were compared on each axis using $t$-tests with site scores as the dependent variable. Letters indicating homogeneous t-test groups $(\mathrm{P}<0.05)$. PC1: Reference $=\mathrm{ab}, \quad$ Restored $=\mathrm{a}, \quad$ Control $=\mathbf{b} ; \quad$ PC2: Reference $=\mathrm{ab}, \quad$ Restored $=\mathrm{a}$, Control $=$ b. Species abbreviations are: Cal_sep $=$ Calystegia sepium, Men_lon $=$ Mentha longifolia, $\quad$ Per_mac $=$ Persicaria maculosa, Pha_aru $=$ Phalaris arundinacea, Pol_avi $=$ Polygonum aviculare, Pop_nig $=$ Populus nigra, Ror_syl $=$ Rorippa sylvestris, Sal_ele $=$ Salix eleagnos, Sal_fra $=$ Salix fragilis, Sal_pur $=$ Salix purpurea, Sal_sal $=$ Salix salviifolia and Sol_dul = Solanum dulcamara. The blue arrow indicates the direction and strength of the correlation between PC1 and PC2 and the d50, i.e., 50th percentile of the grain size ( $\mathrm{PC} 1: \mathrm{P}=0.025, \mathrm{PC} 2: \mathrm{P}=0.086$ ). The blue arrows indicate the direction and strength (see axes values) of the correlations between PC1 and PC2 and the d50, i.e., 50th percentile of the grain size ( $\mathrm{PC1}: \mathrm{P}=0.025, \mathrm{PC} 2: \mathrm{P}=0.086$ ) and the grain size diversity (PC1: $\mathrm{P}=0.024, \mathrm{PC} 2: \mathrm{P}=0.049$ ). (For interpretation of the references to colour in this figure legend, the reader is referred to the web version of this article.)

or revegetation. The key is to "let the river do the work" (Herbkersman, 1982; González del Tánago and García de Jalón, 1995; Stanford et al., 1996).

Also as hypothesized, we did find differences between the plant communities in restored and control river segments, which were mainly 
due to the higher abundance of Persicaria maculosa and woody species in the latter. Persicaria maculosa is an annual forb that tolerates wet conditions and light exposure (Julve, 2015), and its abundance may reflect that the gravel bars in the control segment were the most exposed to the river flow with the least complex channel shape (Table 2). The exception of the restored site RES-3, located in negative side of the PCA together with control sites, could be explained by the gravel bar configuration. Site RES-3 had a very flat surface with an elevation similar to the water level, which makes it susceptible to be frequently flooded even under low flows, leading to present a hygrophilous community more similar to control sites. A wider river channel in the restored segment may have reduced the flow stress on the new gravel bars, facilitating alternative successional pathways, as may occur in the unregulated, reference system. We think that the higher dominance of herbs over woody species in the restored segment compared to the control segment can be explained by the "control" gravel bars being older. With more time to grow, trees and shrubs dominated over smaller life forms. The finer and more homogeneous soil texture observed in control sites may support our conclusion, as fine sediments are deposited in sediment tails downstream from patches of trees following flood events (Rodrigues et al., 2007).

Even though we found significant differences in the plant communities of gravel bars in the restored and control river segments, the differences between bars within the three types of segment were much higher. In our opinion, this observation is evidence that the composition of riparian plant communities is more dependent on local processes, such as the location of the bar within the active channel, its relative elevation, light exposure, and the sediment structure and caliber (geomorphic unit sensu Gurnell et al., 2016; Cordes et al., 1997; Tabacchi et al., 1998), or stochastic processes, such as propagule availability, as shown by other evaluations of restoration in floodplains where levees were modified (Trowbridge, 2007). Whether the fate of the composition of the plant communities in restored segments is more stochastic than deterministic, we suggest that the process of channel widening reproduced the natural formation of gravel bars that follows channel migration in unconstrained rivers. Previous studies have reported the regeneration of disturbance-dependent vegetation following human modification of fluvial landforms: colonisation of poplars and willows after reprofiling of the active channel or the floodplain, mechanical disturbance of competing vegetation, and controlled flooding or irrigation (e.g., Friedman et al., 1995; Geerling et al., 2008; Roelle and Gladwin, 1999; Sher et al., 2002) and manipulation of longitudinal structures (González et al., 2017a; Rohde et al., 2005), but our work is the first evidence that similar positive results can be also achieved over entire longer river sections. That a restoration technique already proven effective at short river segments also works at longer segments may be seen as a trivial conclusion but, in our opinion, it has two remarkable beneficits. First, managers of other rivers around the world may find this project inspiring and encouraging to promote similar initiatives. Second, given the multi-scale hierarchical structure of rivers, restoring longer segments may have synergistic effects on factors operating at higher spatial scales and the positive effects may be multiplied accordingly. Our results did not discard this possibility and warrant further research.

\subsection{Lessons learned from upscaling channel widening to entire river segments}

This study has demonstrated the ecological improvement provided by one of the most ambitious channel widening restoration projects implemented in the world. Ordinary floods that occurred since the project implementation have promoted sediment mobility and channel planform changes under a new, wider active channel created by the project. However, some questions about the effectiveness of this restoration technique remain unsolved. First, the gravel bars that were sampled in the restored segment are still too young to project whether they will contribute to the habitat complexity described in theoretical succession models for natural riparian forests, which consists of a shifting mosaic of forest patches of different ages (Corenblit et al., 2007; Johnson et al., 1976; Merritt, 2013). We believe, though, that given that the migration of the channel is still limited, succession in these sites will be recurrently truncated by flooding disturbance and they will remain in a juvenile stage. González et al. (2017a) reported immature plant communities in sites restored $>5$ years ago. Rohde et al. (2005) noted that the alluvial vegetation establishing at the new sites remained in a young seral stage even 10 years after restoration due to a high level of flooding disturbance in their too small channel widenings. Pasquale et al. (2011) found that new bars formed as a result of set-backing a levee were barely colonized by riparian vegetation and thus unstable: recurrently migrating and disappearing. This does not preclude the possibility that, in sheltered zones, established vegetation could grow and become mature. If the latter is true, the restored sites will approach a higher habitat complexity characteristic of natural riparian forests.

Second, and more important, widening river channels by only a few meters compared to the floodplain width, as was done in the Órbigo River, therefore, would not solve the dichotomy of forest aging in the protected zones of the floodplain while recurrently rejuvenating in the unprotected channel margins, as it has been described for regulated rivers (Cordes et al., 1997; Dixon et al., 2012; González et al., 2010). This restoration strategy would only allow riparian vegetation to persist in the river system and eventually recolonize the floodplain if appropriate conditions, e.g., larger channel migration, are restored in the future. Having the Luna Reservoir immediately upstream from the restored area represents an opportunity to implement environmental flows (sensu Acreman and Dunbar, 2004) as a complementary restoration measure to channel widening and eventually achieve more ambitious ecological improvement. Water releases from reservoirs combined with geomorphic work (e.g., floodplain reconfiguration, site preparation, mechanical clearance of competing vegetation with land contouring) have been implemented to restore riparian vegetation in other rivers of semi-arid regions, such as the Middle Rio Grande in New Mexico (Taylor et al., 1999, 2006; Sher et al., 2002) or the Lower Colorado River from the U.S.-Mexico border to the river delta (Shafroth et al., 2017). That even the positive results of one of the most effective river restoration techniques as reported in this paper were actually very small when framed in the context of the entire floodplain should raise an alarm on how management of riparian systems is not guaranteeing their proper ecological functioning (González et al., 2017b). Successful experiences like those reported here should not leave room for complacency but rather help design integrative conservation strategies for riparian zones that combine even more ambitious ecological-technical actions with socio-economic, educational, political and legal ones (González et al., 2017b).

Third, the data used in this study was collected only once (i.e., one set of aerial photographs post-restoration, one field survey for vegetation) and therefore our study provides just a snapshot of a continuous process of ecosystem recovery. This consideration is especially important for rivers, where a great unpredictability of successional trajectories may be expected (Hughes et al., 2005). We recommend the implementation of monitoring programs durable enough (e.g., several decades) to identify the long-term geomorphic trajectory of the river and the associated plant communities. This future research will define the limits of channel widening as a passive restoration approach, and help to identify, for example, the timing of future interventions (Nilsson et al., 2017), to maintain the natural resilience of the riparian habitats in a context of adaptive management.

\section{Acknowledgments}

VMF was supported by a pre-doctoral scholarship from the Ministerio de Educación, Cultura y Deporte, Spain, FPU 2013. EG's participation in this project and field work were supported by a Marie 
Curie International Outgoing Fellowship within the 7th European Community Framework Programme (ESFFORES project grant number 299044). We thank Ignacio Santillán, responsible of the ecological restoration project of the Órbigo River at the Confederación Hidrográfica del Duero, for his technical support. Prof. Eric Tabacchi is gratefully acknowledged for his help to plant species identification. Comments by Prof. Deborah Kennard greatly contributed to improve the manuscript. We are grateful to two anonymous reviewers for their helpful comments on an earlier version of this manuscript. VMF, EG and JLA conceived the research; VMF and EG wrote and edited the manuscript with the help of DGJ and JLA; VMF, EG, SMG, JLA and DGJ performed the field surveys, VMF and EG analyzed the data.

\section{Appendix A. Supplementary data}

Supplementary data associated with this article can be found, in the online version, at http://dx.doi.org/10.1016/j.ecoleng.2017.08.005.

\section{References}

Acreman, M.C., Dunbar, M.J., 2004. Defining environmental river flow requirements? A review. Hydrol. Earth Syst. Sci. Discuss. 8 (5), 861-876.

Bernhardt, E.S., Sudduth, F.B., Palmer, M.A., Allan, J.D., Meyer, J.L., Alexander, G., Follastad-Shah, J., Hasset, B., Jenkinson, R., Lave, R., Rumps, J., Pagano, L., 2007. Restoring rivers one reach at a time: results from a survey of US river restoration practitioners. Restor. Ecol. 15 (3), 482-493.

Biron, P.M., Buffin-Bélanger, T., Larocque, M., Choné, G., Cloutier, C.A., Ouellet, M.A. Demers, S., Olsen, T., Desjarlais, C., Eyquem, J., 2014. Freedom space for rivers: a sustainable management approach to enhance river resilience. Environ. Manage. 54, 1056-1073.

Bonham, C.D., 1989. Measurements for Terrestrial Vegetation. Wiley, New York.

CHD, 2010. Confederación Hidrográfica del Duero. Sistema Nacional de cartografía de Zonas inundables en la Demarcación Hidrográfica del Duero.

CHD, 2011. Confederación Hídrográfica del Duero. Proyecto de mejora del Estado Ecológico del Río Órbigo (León) Tramo I.

Cordes, L.D., Hughes, F.M.R., Getty, M., 1997. Factors affecting the regeneration and distribution of riparian woodlands along a northern prairie river: the Red Deer River, Alberta, Canada. J. Biogeogr. 24, 75-695.

Corenblit, D., Tabacchi, E., Steiger, J., Gurnell, A.M., 2007. Reciprocal interactions and adjustments between fluvial landforms and vegetation dynamics in river corridors: a review of complementary approaches. Earth Sci. Rev. 84, 56-86.

Dixon, M.D., Johnson, W.C., Scott, M.L., Bowen, D.E., Rabbe, L.A., 2012. Dynamics of plains cottonwood (Populus deltoides) forests and historical landscape change along unchannelized segments of the Misso uri River, USA. Environ. Manage. 49, 990-1008.

Florsheim, J.L., Mount, J.F., 2002. Restoration of floodplain topography by sand-splay complex formation in response to intentional levee breaches Lower Cosumnes River, California. Geomorphology 44 (1), 67-94.

Friedman, J.M., Scott, M.L., Lewis, W.M., 1995. Restoration of riparian forest using irrigation, artificial disturbance, and natural seedfall. Environ. Manage. 19 (4), $547-557$.

Fryirs, K.A., Brierley, G.J., 2013. Geomorphic Analysis of River Systems: An Approach to Reading the Landscape. John Wiley \& Sons, Chichester, UK (p. 345).

Göthe, E., Timmermann, A., Januschke, K., Baattrup-Pedersen, A., 2016. Structural and functional responses of floodplain vegetation to stream ecosystem restoration. Hydrobiologia 769 (1), 79-92.

Geerling, G.W., Kater, E., van der Brink, C., Baptist, M.J., Ragas, A.M.J., Smits, A.J.M., 2008. Nature rehabilitation by floodplain excavation: the hydraulic effect of 16 years of sedimentation and vegetation succession along the Waal River, NL Geomorphology 99, 317-328.

González del Tánago, M., García de Jalón, D., 1995. Principios básicos para la restauración de ríos y riberas. Ecología 9, 34-46.

González del Tánago, M., García de Jalón, D., Román, M., 2012. River restoration in Spain: theoretical and practical approach in the context of the European Water Framework Directive. Environ. Manage. 50, 123-139.

González, E., González-Sanchís, M., Gabezas, A., Comín, F.A., Muller, E., 2010. Recent changes in the riparian forest of a large regulated Mediterranean river: implications for management. Environ. Manage. 45, 669-681.

González, E., Rochefort, L., Boudreau, S., Poulin, M., 2014. Combining indicator species and key environmental and management factors to predict restoration success of degraded ecosystems. Ecol. Indic. 46, 15-166.

González, E., Sher, A.A., Tabacchi, E., Poulin, M., Masip, A., 2015. Restoration of riparian vegetation: a review of implementation and evaluation approaches in the international, peer-reviewed literature. J. Environ. Manage. 158, 85-94.

González, E., Masip, A., Tabacchi, E., Poulin, M., 2017a. Strategies to restore floodplain vegetation after abandonment of human activities. Restor. Ecol. 25, 82-91.

González, E., Felipe-Lucia, M., Bourgeois, B., Boz, B., Nilsson, C., Palmer, C., Sher, A.A., 2017 b. Integrative conservation of riparian zones. Biol. Conserv. 211, 20-29 (Part B).

Gumiero, B., Mant, J., Hein, T., Elso, J., Boz, B., 2013. Linking the restoration of rivers and riparian zones/wetlands in Europe: sharing knowledge through case studies. Ecol. Eng. 56, 36-50.
Gurnell, A.M., Petts, G.F, Hannah, D.M., Smith, B.P.G., Edwards, P.J., Kollmann, J., Ward, J.V., Tockner, K., 2001. Riparian vegetation and island formation along the gravel-bed Fiume Tagliamento, Italy. Earth Surf. Procceses Landforms 26, 31-62.

Gurnell, A.M., Rinaldi, M., Belletti, B., Bizzi, S., Blamauer, B., Braca, G., Buijse, A.D., Bussettini, M., Camenen, B., Comiti, F., Demarchi, L., García de Jalón, D., González del Tánago, M., Grabowski, R.C., Gunn, I.D.M., Habersack, H., Hendriks, D., Henshaw, A.J., Klösch, M., Lastoria, B., Latapie, A., Marcinkowski, P., MartínezFernández, V., Mosselman, E., Mountford, J.O., Nardi, L., Okruszko, T., O’Hare, M.T., Palma, M., Percopo, C., Surian, N., van de Bund, W., Weissteiner, C., Ziliani, L., 2016. A multi-scale hierarchical framework for developing understanding of river behaviour to support river management. Aquat. Sci. 78, 1-16.

Herbkersman, C.N., 1982. A Guide to the George Palmiter River Restoration Techniques. Institute of Environmental Sciences, Miami University of Ohio, Oxford, OH.

Hering, D., Aroviita, J., Baattrup-Pedersen, A., Brabec, K., Buijse, T., Ecke, F., Friberg, N. Gielczewski, M., Januschke, K., Köhler, J., Kupilas, B., Lorenz, A.W., Muhar, S., Paillex, A., Poppe, M., Schmidt, T., Schmutz, S., Vermaat, J., Verdonschot, P., Verdonschot, R., Wolter, C., Kail, J., 2015. Contrasting the roles of section length and instream habitat enhancement for river restoration success: a field study of 20 European restoration projects. J. Appl. Ecol. 52 (6), 1518-1527.

Hughes, F.M.R., Colston, A., Mountford, J.O., 2005. Restoring riparian ecosystems: the challenge of accommodating variability and designing restoration trajectories. Ecol. Soc. $10(1), 12$.

Jähnig, S.C., Brunzel, S., Gacek, S., Lorenz, A.W., Hering, D., 2009. Effects of re-braiding measures on hydromorphology, floodplain vegetation, ground beetles and benthic invertebrates in mountain rivers. J. Appl. Ecol. 46, 406-416.

Johnson, W.C., Burgess, R.L., Keammerer, W.R., 1976. Forest overstory vegetation and environment on the Missouri River floodplain in North Dakota. Ecol. Monogr. 46 (1) 59-84.

Julve, P., 2015. Baseflor. Index botanique, écologique et chorologique de la flore de, France (Accessed September 2016). http://perso.wanadoo.fr/philippe.julve/ catminat.htm.

Krumbein, W.C., 1941. Measurement and geological significance of shape and roundness of sedimentary particles. J. Sediment. Res. 11 (2), 64-72.

Legendre, P., Gallagher, E.D., 2001. Ecologically meaningful transformations for ordination of species data. Oecologia 129, 271-280.

Mahoney, J.M., Rood, S.B., 1998. Streamflow requirements for cottonwood seedling recruitment: an integrative model. Wetlands $18,634-645$

Martínez-Fernández, V., González del Tánago, M., Maroto, J., García de Jalón, D., 2017. Fluvial corridor changes over time in regulated and non-regulated rivers (Upper esla river, NW Spain). River Res. Appl. 33, 214-223.

Merritt, D.M., 2013. Reciprocal relations between riparian vegetation, fluvial landforms, and channel processes. In: Shroder, J.F. (Ed.), Treatise on Geomorphology, Vol 9 , Fluvial Geomorphology. Academic Press, San Diego, pp. 219-243 Wohl, E. (Volume Editor).

Nilsson, C., Sarneel, J.M., Palm, D., Gardeström, J., Pilotto, F., Polvi, L.E., Lind, L. Holmqvist, D., Lundqvist, H., 2017. How do biota respond to additional physical restoration of restored streams? Ecosystems 20, 144-162.

Oksanen, J., Blanchet, F.G., Kindt, R., Legendre, P., Minchin, P.R., O'Hara, R.B., Simpson, G.L., Solymos, P., Stevens, M.H.H., Wagner, H., 2013. Vegan: Community Ecology Package. R package version 2. 0-10 (Accessed October 2016). http://CRAN.Rproject.org $/$ package $=$ vegan .

Ollero, A., 2010. Channel changes and floodplain management in the meandering middle Ebro River, Spain. Geomorphology 117, 247-260.

Pasquale, N., Perona, P., Schneider, P., Shrestha, J., Wombacher, A., Burlando, P., 2011. Modern comprehensive approach to monitor the morphodynamic evolution of a restored river corridor. Hydrol. Earth Syst. Sci. 15, 1197-1212.

Poppe, M., Kail, J., Aroviita, J., Stelmaszczyk, M., Giełczewski, M., Muhar, S., 2016. Assessing restoration effects on hydromorphology in European mid-sized rivers by key hydromorphological parameters. Hydrobiologia 769, 21-40.

Quintana, X., Brucet, S., Gascón, S., Badosa, A., López-Flores, R., Boix, D., Egozcue, J.J., 2008. A non parametric method for the measurement of size diversity, with emphasis on data standardisation. Limnol. Oceanogr.: Methods 14, 75-86.

R Development Core Team, 2016. R: A Language and Environment for Statistical Computing. R Foundation for Statistical Computing, Vienna, Austria. http://www.Rproject.org/.

Rodríguez-Fernández, L.R., 2004. Mapa Geológico de Espańa a escala 1:2.000.000. In Vera, J.A. (Ed.), Geología de España. SGE-IGME, Madrid.

Rodrigues, S., Bréhéret, J.G., Macaire, J.J., Greulich, S., Villar, M., 2007. In-channel woody vegetation controls on sedimentary processes and the sedimentary record within alluvial environments: a modern example of an anabranch of the River Loire, France. Sedimentology 54 (1), 223-242.

Roelle, J.E., Gladwin, D.N., 1999. Establishment of woody riparian species from natural seedfall at a former gravel pit. Restor. Ecol. 7, 183-192.

Rohde, S., Schütz, M., Kienast, F., Englmaier, P., 2005. River widening: an approach to restoring riparian habitats and plant species. River Res. Appl. 21, 1075-1094.

Scott, M.L., Friedman, J.M., Auble, G.T., 1996. Fluvial process and the establishment of bottomland trees. Geomorphology 14, 327-339.

Shafroth, P.B., Schlatter, K.J., Gomez-Sapiens, M., Lundgren, E., Grabau, M.R., RamírezHernández, J., Rodríaguez-Burgueño, E., Flessa, K.W., 2017. A large-scale environmental flow experiment for riparian restoration in the Colorado River delta. Ecol. Eng. http://dx.doi.org/10.1016/j.ecoleng.2017.02.016.

Sher, A.A., Marshall, D.L., Taylor, J.P., 2002. Establishment patterns of native Populus and Salix in the presence of invasive nonnative Tamarix. Ecol. Appl. 12, 760-772

Stanford, J.A., Ward, J.V., Liss, W.J., Frissell, C.A., Williams, R.N., Lichatowich, J.A., Coutant, C.C., 1996. A general protocol for restoration of regulated rivers. Regul. River Res. Manage. 12, 391-413. 
Stewart-Oaten, A., Murdoch, W.M., Parker, K.R., 1986. Environmental impact assessment: 'pseudoreplication' in time? Ecology 67, 929-940.

Tabacchi, E., Correll, D.L., Hauer, R., Pinay, G., Planty-Tabacchi, A.M., Wissmar, R.C.,

1998. Development, maintenance and role of riparian vegetation in the river landscape. Freshw. Biol, 40 (3), 497-516.

Taylor, J.P., Wester, D.B., Smith, L.M., 1999. Soil disturbance, flood management, and riparian woody plant establishment in the Rio Grande floodplain. Wetlands 19 .
$372-382$.

Taylor, J.P., Smith, L.M., Haukos, D.A., 2006. Evaluation of woody plant restoration in the Middle Rio Grande: ten years after. Wetlands 26, 1151-1160.

Trowbridge, W.B., 2007. The role of stochasticity and priority effects in floodplain restoration. Ecol. Appl. 17, 1312-1324.

Wolman, M.G., 1954. A new method of sampling coarse river-bed. Trans. American Geophys. Union 35, 951-956. 